\title{
WAEMU Trade and Current Account Balance Deficit Analysis: A Panel VAR Approach
}

\author{
Amadou Maiga Ousseini' ${ }^{1}$, Xiaojuan Hu', Badamassi Aboubacar ${ }^{2}$ \\ ${ }^{1}$ Department of Economics and Trade, Hunan University, Changsha, China \\ ${ }^{2}$ School of Economics and Management, China University of Geosciences, Wuhan, China \\ Email: Ousseini22000@yahoo.fr, hdhxj@163.com, aboubacarbadamassi@yahoo.fr
}

How to cite this paper: Ousseini, A.M., Hu, X.J. and Aboubacar, B. (2017) WAEMU Trade and Current Account Balance Deficit Analysis: A Panel VAR Approach. Theoretical Economics Letters, 7, 834-861. https://doi.org/10.4236/tel.2017.74060

Received: May 3, 2017

Accepted: June 11, 2017

Published: June 14, 2017

Copyright $\odot 2017$ by authors and Scientific Research Publishing Inc. This work is licensed under the Creative Commons Attribution International License (CC BY 4.0).

http://creativecommons.org/licenses/by/4.0/

\begin{abstract}
Our study focuses on the analysis of the main determinants which have an effect on trade and current account balance. We empirically investigate the effect of money supply (M2), real exchange rate, income, inflation, investment, and house-hold consumption expenditure on the trade and current account balance of WAEMU for the period 1980-2013. The examination of monetary and absorption approaches to the balance of payments motivate the inclusion of income and money supply (M2). The conventional approach of elasticity motivates usage of exchange rates. We adopt the panel VAR method which additionally includes a simulation of variance decompositions and impulse response functions for transmission of shocks and further deductions. The study found a negative and statistically significant effect of money supply, household consumption expenditure on trade Balance. We found also a significant and positive effect of real exchange rate, income, inflation, and investment on the trade balance. A significant and negative relationship between money supply, investment and current account balance was established. The effect of real exchange rate, income, inflation, and household consumption expenditure on the current account balance was found to be positive and significant as well. The significance of exchange rate effect on the trade balance suggests that the Marshall-Lerner condition hold for WAEMU.
\end{abstract}

\section{Keywords}

WAEMU, Trade Balance Deficit, Current Account Deficit, Determinants, Panel VAR

\section{Introduction}

The balance of payments is the projection of the whole international economic 
operations between citizens of a country and the remainder of the world. Balance of payment is an essential tool which informs a country's authorities about the international position of their country. Balance of payment item which is the current account is a principal indicator for a country's decision-making process.

The situation of the balance of payment in majorities of developing countries necessitates the understanding of the current account stance of these countries. Recently, many developed or developing countries show persistent deficits in their balance of payments particularly their current accounts. Except for some European countries like Germany, Austria, Netherlands, Switzerland, Sweden and Ireland which heaped up surpluses, the Central and Eastern European countries are facing deficit [1]. A large deficit is also present in the majority of African countries.

Most of Sub-Saharan African countries' current account and trade balance had not been so encouraging over many years [2]. Thus, it is important to understand the sources of the deficit. The deficit may be occurring under any monetary policies.

Poor economic strategies adopted by these countries may be among principal reasons for such performance. The exports of many of Sub-Saharan African countries are based on raw material. They import more manufactured goods as a consequence of huge trade deficit in their economies. A comparison of countries trade and current account reveals a big gap between the developed and developing countries. Because of the difference in the gap between countries, it is essential to do an investigation about the main determinants which influences the trade and current account balance among countries. There have been various studies about trade balance determinant. There is still being no consensus on the size of the effects of balance trade determinants in spite of the number of studies [1].

West African countries especially WAEMU'S are not exceptions from those which have the current account deficit as we can see from the graph below.

The current account is a substantial indicator of the health of an economy. The current account quantifies trade plus capital transfers. A positive current account balance indicates that the country is a net lender to the rest of the world, while a negative current account balance indicates that it is a net borrower from the rest of the world. A current account surplus increases the net foreign assets of a country by the amount of the surplus and a current account deficit decreases by that amount. A current account deficit is the period when a country imports more goods, services and capital than it exports. It is created when a country depends on foreign capital for investment and spending. Depending on why the country manages the deficit, it could be a positive sign of growth.

According to IMF [3], the WAEMU current account deficit hovered around 5 percent of GDP during the last decade and has been financed mainly by aid and foreign direct investment. Official reserves coverage remains adequate and the real effective exchange rate is broadly in line with the region's fundamentals. Non-price competitiveness, however, needs to improve. In 2012, the current account deficit increased substantially reflecting exceptional factors such as recon- 
struction efforts in Côte d'Ivoire and investment in mining in Burkina Faso and Niger. All the WAEMU countries have experienced current account deficits of various magnitudes over the past decade as showed by Figure 1, with the exception of Côte d'Ivoire which used to record surpluses until recently [3]. The current account deficit is projected to remain high in 2013 for similar reasons, but would decline subsequently as Côte d'Ivoire's reconstruction needs subsidy.

According to $\mathrm{BCEAO}^{1}$ [4], the Union's trade deficit established on the basis of customs statistics improved in 2014. According to [4] the trade balance of the Unions as a whole showed a deficit of 1874.7 billion or 3.9\% of GDP in 2014, compared to 2557.0 billion or $5.7 \%$ of GDP in 2013 , a reduction of 1.8 percentage points of GDP. The current account deficit contracted in 2014 to 2595.9 billion compared to 3028.4 billion in 2013. Excluding grants, it stood at $6.2 \%$ of GDP in 2014 against $7.5 \%$ in 2013, a decrease of 1.3 percent. The decline in the current account deficit is mainly attributable to the decrease in the goods deficit, and the increase in secondary income flows (net current transfers). This evolution was mitigated by the growing deficits of service and primary income deficits [4].

Excluding Côte d'Ivoire which is the only country in the Union having a structurally surplus of foreign trade, the deficit stood at 3718.7 billion or $7.7 \%$ of GDP in 2014. The structural deficit in the other States would improve from one year to the next. The trade deficit recorded for the Union in the absence of data from Côte d'Ivoire being out to $9.1 \%$ of GDP in 2013. The decline in the trade deficit by 1.8 percentage of GDP is in line with the improvement in the term of trade which is an indicator of the purchasing power of exports. Determined on the basis of the evolution of the average prices of the exchanged products, they increased by $29.6 \%$ in 2014 against a decrease of $8.8 \%$ in 2013. Increase due in particular to the decrease in international oil prices and the appreciation of the US dollar against the euro [5].

The WAEMU Economic growth has been strong in the last few years. According to IMF [6], the recent period of strong growth in the region has benefited from a post-conflict catch-up effect in Côte d'Ivoire and from larger scale infrastructure investments in the region. Growth in WAEMU remains robust and inflation subdued. The economic activity in the WAEMU remained strong while average economic growth in Sub-Saharan Africa has been slower than expected. It reflected weak commodity prices and also difficult financing conditions. Regional real GDP growth is estimated to have reached 6.4 percent in 2015 , driven by continuing investments in infrastructure, solid private consumption, and favorable agricultural campaigns. The inflation remained subdued reflecting the exchange rate anchor and favorable terms of trade developments.

According to the same report, the economic activity in WAEMU remained strong while the average growth in sub-Saharan Africa has been slower than ex${ }^{1}$ The Central Bank of West African States is a central bank serving the eight West African countries which comprise the West African Economic and Monetary Union (WAEMU). 


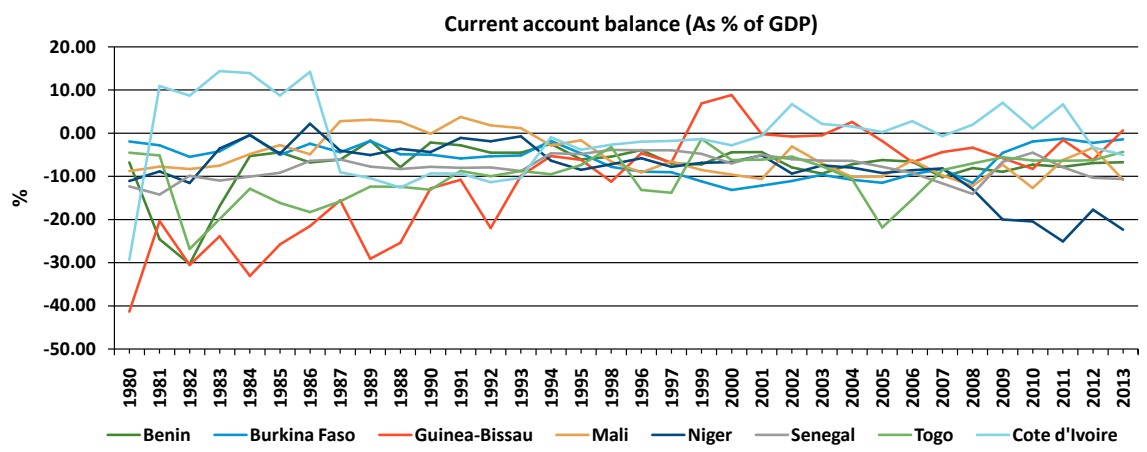

(a)

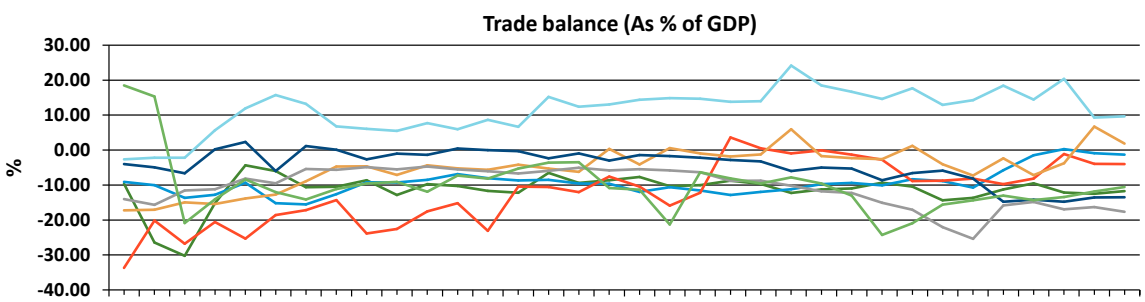

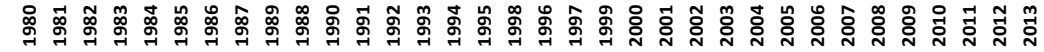

—Benin - Burkina Faso - Guinea-Bissau - Mali -Niger - Senegal — Togo — Cote d'Ivoire

(b)

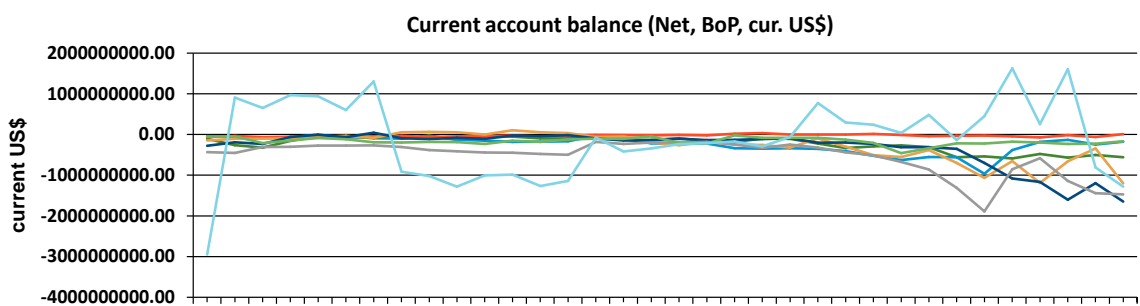

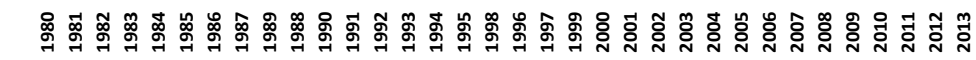

—Benin - Burkina Faso - Guinea-Bissau - Mali —Niger - Senegal - Togo — Cote d'Ivoire

(c)
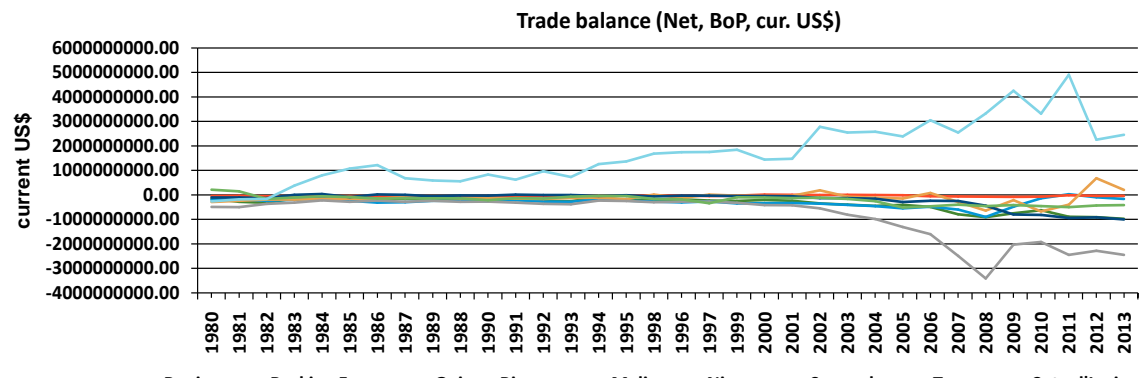

—Benin —Burkina Faso — Guinea-Bissau - Mali —Niger —Senegal — Togo —Coted'Ivoire

(d)

Figure 1. Trade and current account balance trend of WAEMU ${ }^{2}$ countries (Source: Knoema).

${ }^{2}$ The West African Economic Monetary Union (WAEMU) is a trade and currency union of eight countries which share a common colonial French language. The countries member of this union are Benin, Burkina Faso, Cote d'Ivoire, Guinea-Bissau, Mali, Niger, Senegal and Togo. We analyze the eight countries as a group because of their monetary policy is implemented at a union level. These countries trade virtually with the same set of partners and they have similar production structures and use the same currency which is XOF or the CFA franc. 
pect. The growth of real GDP is estimated reached 6.4 percent in 2015. Continuing investments in infrastructure, solid private consumption, and favorable agriculture campaigns driven the growth of real GDP. The regional inflation is subdue controlled which reflect the exchange rate anchor and positive terms of trade developments. The regional current account deficit remains large in spite of lower energy prices. The fall of oil prices has lightened the energy invoice for WAEMU countries while some commodities like cocoa and groundnut prices remained floatable, thereby improving the trade balance. However, the sudden rise of imports, related with public investment and private consumption partly offset the effect of lower energy bills. Thus, the region's overall current account deficit has improved somewhat from 6.1 to 5.6 percent of regional GDP [6].

According to estimation, the current account deficit of WAEMU improved slightly in 2015. Given fiscal consolidation and increased exports, the current account is expected to stabilize at above $6 \%$ of GDP and be fully funded during the projection period. Reserves coverage remains broadly adequate according to traditional metrics.

The regional current account deficit (including grants) continued to decrease from 6.1 percent of GDP in 2014 to at 5.6 percent of GDP in 2015 reflecting more favorable terms of trade. Current and capital transfers have declined slightly by about 0.2 percentage points to about 5.5 and 1.7 percent of GDP, respectively. The current account deficit is expected to increase to 6.4 percent of GDP in 2018, owing to important investment-related imports, and remain at this level over the medium term. FDI and capital transfers are expected to remain the main source of external financing.

Despite the relatively extensive body of theoretical literature on the subject, there are only a few comprehensive cross-country studies that empirically analyze the effect of macroeconomic variables on the Trade and current account balance deficit or determinants of trade and current account balance deficit especially in West African Economic and Monetary Union (WAEMU).

The contribution of this paper to the literature is that this study will allow understanding the effect of money supply, exchange rate, income, investment on the trade balance and current account balance in case of WAEMU or understanding some policies on the trade and current account balance.

Among motivations of this study is that the countries concerned by this analysis have conventional economics characteristics. They face a deficit in their trade and current account balance. These countries have a common currency which is the Franc CFA (XOF) and a common monetary policy. They also have a joint trade agreement, policy and a common official language.

The paper introduces three main goals. The first is to point out the evolution of the trade and current account balance in WAEMU. The second is to examine empirically the linkage between trade and current account balance deficits and a broad and comprehensive set of variables suggested by the theoretical and empirical studies. The last is discussing the way to reduce deficit in WAEMU.

In the aim to accomplish the task, we intend to add large and consistent ma- 
croeconomics variables. We will also focus on developing countries precisely WAEMU countries by running on a panel data set which includes all the eight (8) member of the Economics and Monetary Union and considering annual information for the period 1980-2013.

For decades, many African countries particularly Sub-Saharan African Countries have faced with Trade and current account deficits. Some countries, specifically WAEMU's can be offer as a good example because these countries are facing trade and current account deficit before and after execution of the structure adjustment program (SAP). For the reason of the protracted deficit these countries except for Cote d'Ivoire, it makes sense to continue reconsider some strategies and factors that could be the principal reason of this deficit.

The primary purpose of this research is assessing by estimating and point out the main factors that affect the WAEMU countries trade and current account balance. The specific purpose of the analysis are to find out the impact of the money supply, exchange rate, income, investment or the principal causes of the trade and current account deficit in the aim of adopting new policy measures to diminish the stance of trade and current account deficit which lies in FCFA area balance of payments. For simplicity, we will focus mostly on the impact of monetary policy or the money supply, income, real exchange rate impact on trade balance and current account in the WAEMU.

The importance of our study is to come up with a strong comprehension of the factors influencing the trade and current account. It is also for picking out in which point WAEMU is not doing better, aiming to do more endeavors and deeds which can be adopt to enhance economy. It will lead to increase of exports and decrease of imports therefore lessen the spectrum of current account deficit the WAEMU economic erea and achieve a surplus.

The study considers both the trade in goods and services and current account balance in WAEMU. It considers a period of about thirty-three years (19802013). The selection of the interval of study is made depending on the handiness of the data for most of the variables which will be used in the analysis.

It should be note that most of the previous scholars which considered mostly domestic income, real exchange rate, foreign direct investment (FDI), foreign income, and money supply. Our analysis tries to cover to explore the effect of Money Supply, Income growth proxies by GDP growth, investment proxies by foreign direct investment, Inflation, and household expenditure focusing principally and only on the eight (8) countries member of West African Economics and Monetary Union that have the same currency.

We organize the paper as follows. The first Section introduce and the highlight current economic situation. The second Section provides the literature review. The third Section shows the modeling framework. The fourth Section deals with Empirical framework and section five conclude and recommendations.

\section{Literature Review}

Many researchers conducted researches on problems related to the determinants 
of trade and current account which provided mixed results using different levels of data. Among the relevant literature are the study carried out by [7] which investigated about Kenya's the determinants of trade balance. He discovered that money supply (M3), real exchange rate, government's consumption expenditure and domestic income were the major significant factor while foreign income was not a significant factor. [8] studied the determinants of the Turkish trade balance. They used Autoregressive distributed lags (ARDL) method. The results showed that the depreciation of exchange rate enhance significantly trade balance whereas the impact of real national income on trade balance is negative. An increase in foreign income strongly improves trade balance in turkey. [9] in their study analyzed the determinants of trade balance in case of Bangladesh using dynamic panel data. They found significant effect of import-weighted index in short and long-run but the other variables are significant only in shor-run. [10] explored the effect of the real effective exchange rate on trade balance for five major OECD countries. Her finding is that the effect of exchange rate on the trade balance is a statistically insignificant. [11] [12] found a strong relationship between trade balance and real effective exchange rate, but most studies showed the poor statistical correlation among the variables and trade balance. [13] examined Tanzania's determinant of trade balance in Tanzania. He focused his study on trade in goods and used real exchange rate, foreign income, FDI, household consumption, Government expenditure, and Trade liberalization. $\mathrm{He}$ found out that Government spending, household consumption and trade liberalization are the principal determinants of Tanzanian trade balance. [14] analyzed of the short-run and the long-run relation among the trade balance, exchange rate, income and money supply in Malaysia using the ARDL cointegration approach. He used monetary absorption method instead of conventional absorption approach by including income and money variables. [14] found a statistically insignificant but positive relationship between the exchange rate and trade balance. The money supply has a strong negative effect on trade balance. Income has positive impact on the trade balance. His study suggested the absence the Marshall-Lerner condition in the long run in case of Malaysia.

An analysis on Association of South East Asian Nations countries conducted [15] indicates that trade balance is affected in the countries which change real effective exchange rate, not the nominal effective exchange rate. [16] found a non-significant effect of real exchange rate on balance of payments in an analysis of bilateral flows between United states and other OECD counties using quarterly data. [17] [18] [19] and some researchers clarify the variations in the real effective exchange rate that would affect positively trade balance in some countries, but that is not consistent for all countries. The direction of the trade balance and the real effective exchange rate is uncertain. [1] studied the "Determinants of the Trade Balance in Industrialized Countries" which considered 32 emerging and industrialized economies. He used fixed-effects models and linear-mixed models. The analysis showed that trade balance has a significant positive relation to real foreign GDP per capita of the trade partners. Real domestic GDP per capita is 
found to have an adverse or negative impact on trade balance.

Many studies investigated the determinant of current account balance. [20] empirically examined Medium-term determinants of current account. Their study includes a sample of industrial and developing countries. They employed both panel and cross section regression methods. Fiscal balance, net foreign assets stock, relative per capita income, dependency ratios, real gross domestic product growth, gross domestic product growth volatility, terms of trade volatility, real exchange rate, trade openness, financial deepening, capital controls and saving ratio were some of the variables that are considered. They exposed that current account balance is positively affected by fiscal balance, relative per capita income, financial deepening, net foreign assets, capital controls and terms of trade volatility. In contrast, current account balance is negatively impacted by trade openness and dependency ratio. [21] applying cointegration analysis and Error Correction Model pointed out that the real interest rate and the real effective exchange rate had the highest effect on current account improvements between 1995 and 2006 in Greece. It has been established that increasing budget deficits also contribute to increasing current account deficits. [22] used both the panel regression and panel VAR methods to analyze the impact of fiscal policy on the current account.

They used a large sample of advanced, emerging and low-income economies, concluding that by strengthening the budgetary balance by $1 \%$ of GDP, the current account would improve by $0.3 \%$ of GDP. [23] applied the autoregressive variance to obtain the determinants of the current account balance in Turkey. They used current account balance, GDP growth rate, investment, economies, terms of trade and oil imports, inflation and the real exchange rate were used as variables in the model. The results indicated that the current account balance was mainly affected by inflation and the values of the current account itself. In one quarters, it was established that innovations account for $40 \%$ of the variation in forecasting error of the current account balance in its own past and inflation caused $26 \%$. The current account balance is also affected by changes in growth, saving-to-GDP ratio, investment/GDP ratio, openness, oil prices and the real exchange rate. Other elements are innovations in growths, openness, savings, oil prices, the real exchange rate and investments. [24] using panel regression and panel autoregression over 42 states revealed that a percentage point improvement in fiscal balances improved the current account balance by 0.4 percentage point of GDP. They also indicated that the real effective exchange rate had no effect on the current account balance. [25] used data covering the Kenya period from 1970 to 2010 and applying the vector error correction model.

The results indicated that economic growth accounts for $16.18 \%$ of the current account. The exchange rate the budget deficit and inflation explained $17.97 \%, 14.74 \%$ and $15.31 \%$ respectively. Trade balance explained $13.88 \%$ of current account in the long-run. On the other hand, the effect of the budget deficit and the current account balance itself are positive, while the growth rate, trade balance, investment, inflation, the current account exchange rate are nega- 
tive. The effects of saving on the current account and investment were negative and positive on a small scale during the period under study.

\section{Modeling Framework}

In term of methodology, we use recently developed Panel Vector Auto-Regression technique by Michael R. M. Abrigo and Inessa Love [26]. We use their method to estimate the effect of money supply (M2), real exchange rate(exrat), income (GDP), inflation (inflat), investment (FDI) and household consumption expenditure (HCEX) on Trade and Current Account balance in WAEMU. Our study follows previous works of [14] [27] [28] [29].

We begin by specifying the production function. We include money supply (M2), exchange rate (rexrat), income (GDP), inflation (inflat), investment (FDI) and household consumption expenditure (HCEX) as factors determinants of trade balance (TRB) and current account balance (CA).

$$
\begin{aligned}
& \mathrm{TRB}=(\mathrm{M} 2 \text {, rexrat, GDPG, inflat, FDI, HCEX, } v) \\
& \mathrm{CA}=(\mathrm{M} 2 \text {, rexrat, GDPG, inflat, FDI, HCEX, } v) \\
& \mathrm{TRB}_{i t}=\mathrm{M}_{i t}^{\beta_{1 i}} \operatorname{rexrat}_{i t}^{\beta_{2 i}} \mathrm{GDPG}_{i t}^{\beta_{3 i}} \text { inflat }_{i t}^{\beta_{4 i}} \mathrm{FDI}_{i t}^{\beta_{5 i}} \operatorname{HCEX}_{i t}^{\beta_{6 i}} \\
& \mathrm{CA}_{i t}=\mathrm{M}_{i t}^{\beta_{1 i}} \text { rexrat }_{i t}^{\beta_{2 i}} \mathrm{GDPG}_{i t}^{\beta_{3 i} i n f l a t}{ }_{i t}^{\beta_{4 i}} \operatorname{FDI}_{i t}^{\beta_{5 i}} \operatorname{HCEX}_{i t}^{\beta_{6 i}}
\end{aligned}
$$

following empirical panel form of the model is specified and estimated

$$
\begin{aligned}
\operatorname{trb}_{i t}= & \beta_{0}+\beta_{1} \mathrm{M}_{i t}+\beta_{2} \text { rexrat }_{i t}+\beta_{3} \mathrm{GDPG}_{i t}+\beta_{4} \text { inflat }_{i t} \\
& +\beta_{5} \mathrm{FDI}_{i t}+\beta_{6} \mathrm{HCEX}_{i t}+v_{i t} \\
\mathrm{CA}_{i t}= & \beta_{0}+\beta_{1} \mathrm{M}_{i t}+\beta_{2} \text { rexrat }_{i t}+\beta_{3} \mathrm{GDPG}_{i t}+\beta_{4} \text { inflat }_{i t} \\
& +\beta_{5} \mathrm{FDI}_{i t}+\beta_{6} \mathrm{HCEX}_{i t}+v_{i t}
\end{aligned}
$$

We derive the equation (5) and (6) in panel vector autoregressive model based on Abrigo and Love (2015) method as follow:

$$
\begin{aligned}
Y_{i t}= & Y_{i t-1} A_{1}+Y_{i t-2} A_{2}+Y_{i t-3} A_{3}+\cdots+Y_{i t-p+1} A_{p-1}+Y_{i t-p} A_{p} \\
& +X_{i t} B+u_{i t}+e_{i t}, i \in\{1,2, \cdots, N\}, t \in\left\{1,2, \cdots, T_{i}\right\}
\end{aligned}
$$

where $Y_{i t}$ is a $(k \times k)$ vector of dependent variables (trade balance and current account balance); $X_{i t}$ is a $(1 \times l)$ vector of exogenous covariates; $X_{i}$ and $e_{i t}$ are $(1 \times k)$ vectors of our dependent variable-specific fixed-effects and idiosyncratic errors, respectively. The $(k \times k)$ matrices of $A_{1}, A_{2}, \cdots, A_{p-1}, A_{p}$ and the $(l \times k)$ matrix $B$ are parameters to be estimated. It is assumed that the changes or innovations have the following features: $E\left[e_{i t}\right]=0, E\left[e_{i t}^{\prime} e_{i t}\right]=\Sigma$ and $E\left[e_{i t}^{\prime} e_{i s}\right]=0$ for all $t>s$.

[26] based their method of estimation of the Panel VAR model and used in our estimation on GMM. Equation-by-equation GMM estimation gives consistent assessments of panel VAR, estimating the model as a system of equations may effect to efficiency gains [30]. Suppose the mutual set of $L \geq k p+l$ instruments is determined by the row vector $Z_{i t}$, where $X_{i t} \in Z_{i t}$, and equations are indexed by a number in superscript. Consider the following processed panel VAR model based on Equation (1) but represented in a more compact form [26]. 


$$
Y_{i t}^{*}=\overline{Y_{i t}^{*}} A+e_{i t}^{*}
$$

The General Method of Moment estimator is deriving as:

$$
A=\left(\overline{Y^{*}} Z \hat{W} Z^{\prime} \bar{Y}^{*}\right)^{-1}\left(\overline{Y^{*}} Z \hat{W} Z^{\prime} \overline{Y^{*}}\right)
$$

where $\hat{W}$ is a $(l \times l)$ weighting matrix supposed to be non-singular, symmetric and positive semi-definite. Assuming that

$$
E\left[Z^{\prime} e\right]=0 \text { and } E\left[{\overline{Y^{*}}}^{\prime} Z\right]=k p+l k p+l
$$

the GMM estimator is consistent. The weighting matrix $\hat{W}$ may be selected to maximize efficiency [31].

The hypothesis of our analysis is a null-impact of explanatory variables on the dependent variable. It endeavors to uncover $i$ four explanatory variables have significant impacts on trade and current account or not:

$$
\begin{aligned}
& H_{0}: \tau=0 \\
& H_{1}: \tau \neq 0
\end{aligned}
$$

\section{Empirical Framework}

\subsection{Explanation and Sources of the Variables}

Trade balance (TB): we consider the traditional measure of trade balance as the difference between the total values of exports and total imports. The source trade balance data is African Development Bank Database (AFDB-socio-economic) from 1980 to 2013.

Current account balance: The difference between a country's savings and the investment. It is an important indicator of the health of an economy. It is defined as the sum of the balance of trade, net income from abroad and net current transfers. The source of current account balance data is African Development Bank Database from 1980 to 2013.

Money supply: the money supply is considered to be a critical element in determining economic activity. The choice of money supply as explanatory variable is justify by the argument that there is the monetary approach which argue that Any deficit in the balance of payments is due to the excess of money [28] and concerning the or global monetarist approach [32] [33] [34]. The balance of payments is essentially a monetary phenomenon. The behavior of the balance of payments is analyzed in terms of supply and demand for money. In very simple terms, if people ask for more money than those provided by the Central Bank, excess demand for money would be satisfied by flows of money from abroad. In this case, the trade balance will improve. On the other hand, if the Central Bank provides more money than is requested, the excess money is eliminated by outflows of money to other countries, which will worsen the trade balance [14]. Our study considers the M2 measures of money supply. The source of Money supply (M2) data is African Development Bank Database (AFDB-socio-economic) from 1980 to 2013. 
Real exchange rate (REEXR): An increase of domestic price (evaluation/appreciation) mean import will become expensive than Exports. According to [12] to gain international competitiveness and help improve the performance of its trade balance, a country may allow the devaluation of the currency or depreciation. The decrease in the real exchange rate (devaluation/depreciation) can lead to deterioration in the trade balance.

In theory, the exchange rate has an effect on the current account. In the event of a depreciation of the exchange rate, the country will experience a decrease in the foreign price of its exports. The exports will appear more competitive, and there will be an increase in its quantity. Assuming that export demand is relatively elastic; depreciation will increase the value of exports and thus ameliorate the deficit of current account. Similarly, a depreciation of the exchange rate will also increase the cost of purchasing imports and will cause a drop in import demand and will also help to reduce the current account deficit. Therefore, in theory, exchange rate depreciation should improve the current account, and appreciation should worsen the current account.

In this case, we expect a negative sign. A higher exchange rate can be expected to lower the country's trade balance, while a lower exchange rate would increase it. The source of Real exchange rate data is from African Development Bank Group Database (AFDB-socio-economic) from 1980 to 2013.

Income: proxies by Gross Domestic Product (GDP growth), the sign on domestic to domestic trade balance is uncertain. It depends on whether it determines the level of economic activity. It can also be considered as a supply variable measuring the supply of exportable. Thus, economic growth has a direct link with an augmentation in the imports value that, other things being equal will driver to a rise in the current account deficit. However, it depends very much on the marginal propensity to import the country. This notion can be defined as the proportion of an additional unit of income that will be spent on imported products. Assuming that the marginal propensity to import is high, then a rise in incomes will have a greater impact on the current account deficit than if it is low, as this implies that the level of imports varies narrowly with changes in income. We expect income to have a positive sign on trade balance (deficit) which means an increase in the nations which imports excess exports' income should increase the deficit. GDP growth data source is also the African Development Bank Group Database (AFDB-socio-economic) from 1980 to 2013.

Inflation (INF): We can define inflation as a sustained increase in the overall level of prices of goods and services in an economy. Prolonged periods of high inflation can drive to persistent current account deficits. High inflation points out that the domestic prices are rising promptly, and it can mean that domestic production becomes less competitive relative to imported goods and services since it becomes relatively more expensive compared to abroad. The current account deficit may be occurring under any monetary policies. But today, since inflation targeting was as a monetary policy framework since the early 1990s, and being a popular strategy has a strong influence on the current account balance. 
Thus many economists argued the impact of inflation on current account deficit significantly [35].

[36] [37] studied the transmission channels of inflation targeting on the current account and, through their studies, the direct channel in which inflation targeting policy affects the current account is the real exchange rate. If there is an increase in the exchange rate (depreciation), it will positively affect inflation. The inflation targeting policy could negatively affect the current account through increases in consumption and investment [35]. The source of Inflation data is the African Development Bank Database (AFDB-socio-economic) from 1980 to 2013.

Investment (Inv): we use foreign direct investment as a proxy for investment. Investment led to the improvement of trade balance and current account balance, especially if the motives of foreign companies are for exports. Economies may also be subject to persistent current account deficits if their level of investment is low to allow exports of high (or even moderate) valuables items. For example, low-investment economies may need to rely on exports of raw and unprocessed commodities that can be highly valued if processed locally. Our expectation is to find negative sign because of the deficit of current account and trade in WAEMU so that an increase in investment will contribute to reducing the countries' deficit. The source for FDI is IMF-International Financial Statistic (IFS) database.

Household Consumption Expenditure (HCEXP): it is a transaction from the national account that represents consumer spending. It consists of expenditure incurred by resident households on individual consumption of goods and services. A rise of Household consumption expenditure tends to deteriorate trade balance. HCEXP can increase import which might be due to the growth in income. As a consequence, we expect its sign to be negative. The source for HCEXP is the IMF-International Financial Statistic (IFS) database.

\subsection{Units Root Test}

The first step of the analysis before the model estimation concerns testing of the variables for a unit root. It will legitimate the choice of the model, and because VAR model necessitates stationary variables if some or variables contain a unit root, then they should be stationary before the model estimation. Here we perform some tests of unit roots on the panel datasets. Im-Pesaran-Shin, the Fishertype test will also be used for imbalance variables.

Table 1 shows the results of stationary tests. It indicates that some of the variables in the study are stationary at level. These variables are trade balance (TRB), FDI (foreign direct investment) as a proxy for investment, Inflation (INFL), GDP growth (proxy to income), and household consumption expenditure (HCEX). Other variables are not stationary at level, but they become stationary after first difference. Those variables are M2 (money supply) and Exchange Rate (EXRAT). The data under study is a mix of variables with different levels of integration, I(0) variables and I(1). 
Table 1. Stationary test for variables.

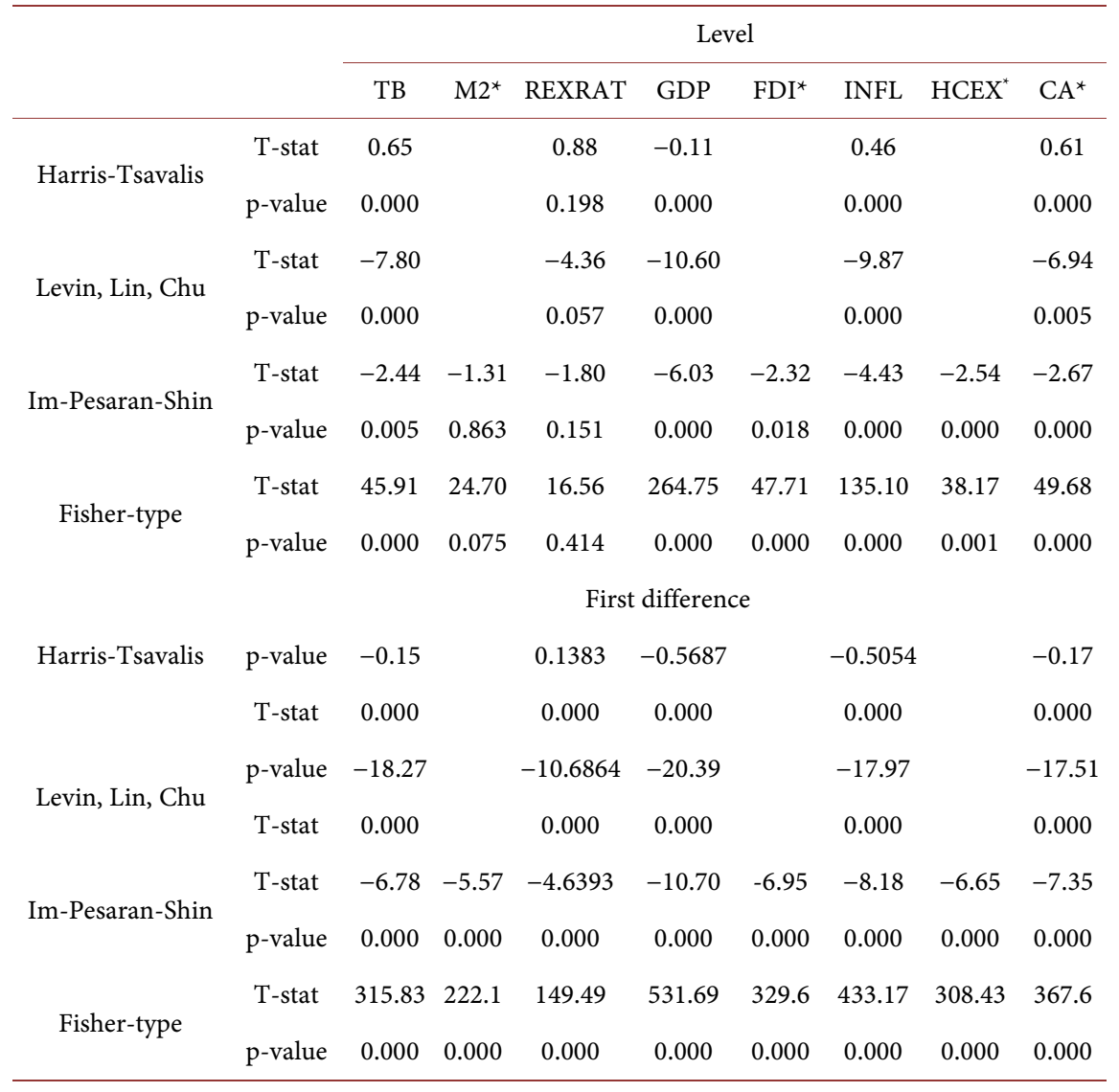

*Not strongly balanced data.

\subsection{Empirical Analysis}

We choose the VAR methodology of the Panel for estimation, as the Panel VAR seem to be particularly well suited to the issues that are currently at the center of discussions in academics and policy areas. Panel VAR can (i) capture static and dynamic interdependencies, (ii) Panel VAR can treat the links across units in an unrestricted fashion, (iii) It can easily incorporate time variations in the coefficients and the variance of shocks, and (iv) cross-sectional dynamic heterogeneities [38].

PVAR is a system that processes the time path of each endogenous variable according to its own present and the past achievements of the other variables of the system [39].

The Prediction of Panel VAR study is made on the selection of the optimal lag order in both the specification panel VAR and moment condition. [40] came up with a consistent moment and model selection criteria (MMSC) for GMM models based on j-statistic of over-identifying restrictions [38]. According to [26], their proposed MMSC are analogous to various commonly used maximum likelihood-based model selection criteria. These criteria are the Akaike information criteria (AIC) [41], the Bayesian information criteria (BIC) [42] [43] [44], and the Hannan-Quinn information criteria (HQIC) [45]. Applying Andrews and Lu's MMSC to the GMM estimator (3), their proposed criteria select the pair of vectors $(\mathrm{p}, \mathrm{q})$ that minimizes, $\mathrm{MMSC}_{\mathrm{AIC}}, \mathrm{MMSC}_{\mathrm{HQIC}}$. 
Based on the model selection criteria by [40] and the overall coefficients of determination, first-order panel VAR is our favor model since it has the smallest MBIC, MAIC and MQIC with a value of $-404.089,-77.010$, and -209.264 respectively. They are $-409.54,-82.461$ and -214.715 in the second part of Table 2 (current account as the dependent variable).

Based on MBIC, MAIC, and MQIC (the selection criteria), we fit a first-order panel VAR model with the same specification of instruments like the above using GMM estimation implemented by the P-VAR model [26]. We note that we cannot yield the estimated output when the specification of the lag instruments is not appropriate.

\subsection{Model Estimation and Interpretation}

Table 3 and Table 4 show the empirical results of models. The effect of money supply (M2) is found to be significantly negative on the trade balance Table 3 .

Table 2. Selection order criteria.

\begin{tabular}{|c|c|c|c|c|c|c|c|}
\hline \multicolumn{8}{|c|}{$\begin{array}{c}\text { Sample: } 1984-2012 \text { No. of obs }=216 \\
\text { No. of panels }=8 \\
\text { Ave. No. of } \mathrm{T}=27.000\end{array}$} \\
\hline \multirow{4}{*}{ TRB } & Lag & $\mathrm{CD}$ & $\mathrm{J}$ & J P-value & MBIC & MAIC & MQIC \\
\hline & 1 & 0.992 & 118.989 & 0.073 & -404.089 & -77.010 & -209.264 \\
\hline & 2 & 0.995 & 58.312 & 0.170 & -203.227 & -39.687 & -105.814 \\
\hline & 3 & -40.707 & . & . & . & . & . \\
\hline \multirow{3}{*}{$\mathrm{CA}$} & 1 & 0.994 & 113.538 & 0.134 & -409.54 & -82.461 & -214.715 \\
\hline & 2 & 0.994 & 63.649 & 0.077 & -197.89 & -34.350 & -100.477 \\
\hline & 3 & 0.984 & . & . & . & . & . \\
\hline
\end{tabular}

Table 3. Model estimation output ${ }^{*}$.

\begin{tabular}{|c|c|c|c|}
\hline & Coefficient & T-value & $P$-value \\
\hline Trade Balance & $-0.574(0.048)$ & -11.76 & 0.000 \\
\hline Money supply (M2) & $-0.027(0.003)$ & -8.64 & 0.000 \\
\hline Real Exchange Rate & $0.010(0.003)$ & 2.67 & 0.008 \\
\hline Income & $0.094(0.040)$ & 2.32 & 0.020 \\
\hline Inflation & $0.063(0.023)$ & 2.68 & 0.007 \\
\hline Investment & $0.047(0.157)$ & 0.30 & 0.763 \\
\hline Household Consumption Expenditure & $-0.243(0.063)$ & -3.82 & 0.000 \\
\hline \multicolumn{4}{|c|}{ GMM Estimation } \\
\hline \multicolumn{4}{|c|}{ Final GMM Criterion $\mathrm{Q}(\mathrm{b})=0.538$} \\
\hline \multicolumn{4}{|c|}{ Initial weight matrix: Identity } \\
\hline \multicolumn{4}{|c|}{ GMM weight matrix: Robust } \\
\hline \multicolumn{4}{|c|}{ Number of observation $=234$} \\
\hline \multicolumn{4}{|c|}{ Number of panels $=8$} \\
\hline \multicolumn{4}{|c|}{ Ave. No. of $\mathrm{T}=29.250$} \\
\hline $\begin{array}{l}\text { Instruments : lags }(1 / 3) \text { of (trade balanc } \\
\text { Investment, household consumpt }\end{array}$ & $\begin{array}{l}\text { ney supply (M2) } \\
\text { xpenditure requir }\end{array}$ & $\begin{array}{l}\text { ge rate, In } \\
\text { e model es }\end{array}$ & $\begin{array}{l}\text { inflation, } \\
\text { on) }\end{array}$ \\
\hline
\end{tabular}


Table 4. Model estimation output.*

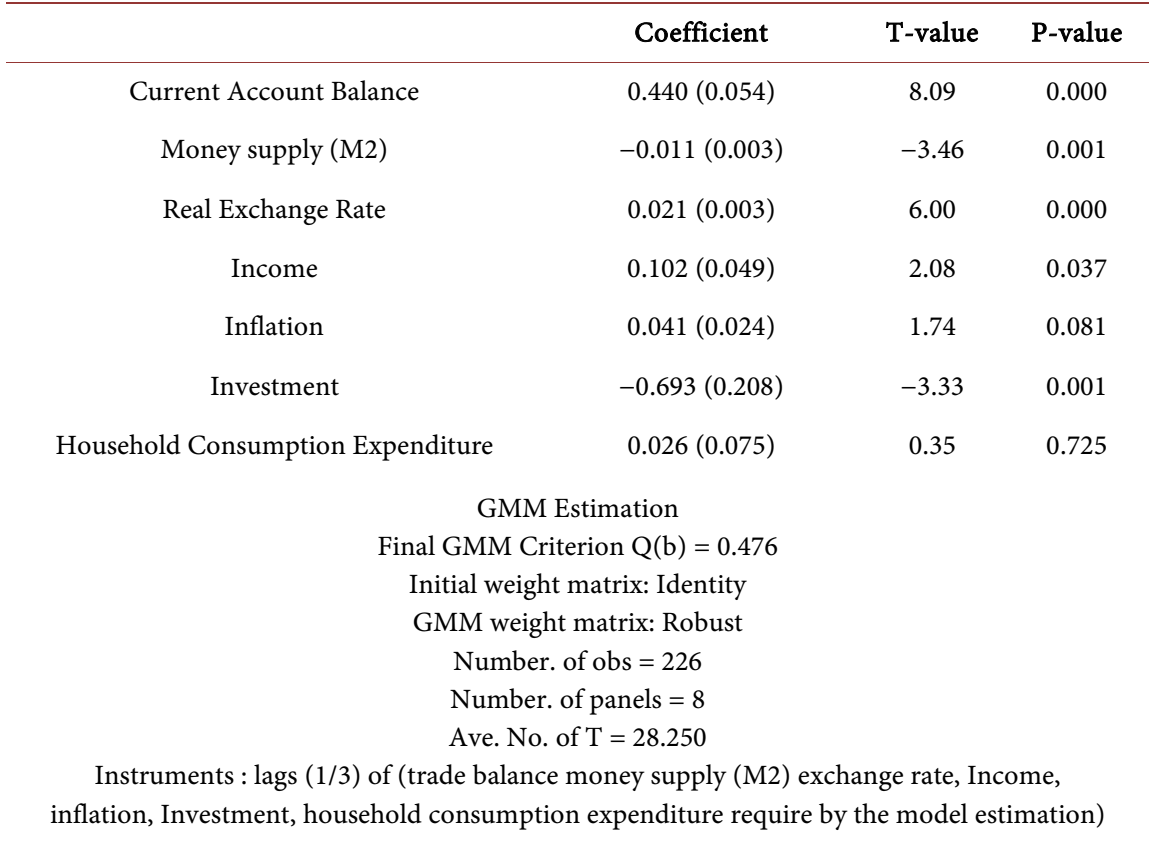

${ }^{*}$ Current account balance as dependent variable.

The effect of money supply is also negative and significant on current account balance Table 4. The fall in the money supply can be explained as the result of tight monetary policy in WAEMU for the aim of inflation control whereas supplying suitable liquidity to boost growth. The policy of money supply (M2) in WAEMU have a significant impact on trade and a percentage increase in money supply results in -0.027 percent decreases in the trade balance deficit and -0.011 percent in current account balance deficit ${ }^{3}$.

The effect of income is found to be positively significant. Money supply (M2) and Income coefficients sign are consistent to monetary theories. Our estimate reveals that an increase in income raises the trade balance deficit by 0.094 percent and it raises current account by 0.10 percent. Theories indicate that an increase in domestic income will increase the demand for money and thus increase exports and improve the trade balance [14].

Another variable which has a significant effect on the trade balance Table 3 and the current account balance Table 4 is inflation. The model estimation output displays a positive sign between inflation and trade balance (deficit) so with the current account balance in WAEMU. It reveals that an increase in inflation worsens the trade and current account balance deficit. Inflation influences the Trade Balance through the balance of payment. The balance of payments may deteriorate because domestic inflation stimulates import spending, as imports seem relatively cheaper and amortize export sales, as exports appear to be more expensive abroad. So Inflation will cause the prices of the goods and services to

${ }^{3}$ WAEMU counties' trade and current account balance are in deficit. The deficit in current accounts tends to be persistent. Cote d'Ivoire is the only country which trade balance is not in deficit and does not have a persistent current account deficit. 
rise. Inflation makes the country's exports less competitive in the international market. The estimate tables show that a rise in inflation worsens current account and the trade balance deficit.

The Institutional Reform of the WAEMU and the BCEAO, which came into effect on first April 2010, established for the Central Bank, an explicit objective of price stability. The framework carried out by noitutitsni gniussi to reach this goal comes in three parts and among the goals is using the inflation forecast as the main indicator of monetary policy and the adoption by the Monetary Policy Committee on a quarterly basis, the measures necessary to achieve the objective. The effect of inflation on the trade balance is relatively weak as shown by the estimation. So we can conclude the evolution of inflation in WAEMU have a significant impact on trade balance.

The real exchange rate is an essential target explanatory variable in our analysis. The coefficient of real exchange rate with trade balance is positive and significant. It has also significant effect on the current account. The significance of this variable implies that the condition of Marshall-Lerner is holding in the case of WAEMU. This result differs from those which revealed that the role of the exchange rate is insignificant in introducing changes in the trade balance, as in the case of Malaysia, Singapore, Thailand and the Philippines [14]. Our study shows that when exchange rate increases by one pour cent, that will worsen trade balance by 0.010 percent and increase current account deficit by 0.021 percent. The reverse will reduce the persistent deficit in WAEMU which can explain the exchange policies adopted by the Central Bank (BCEAO). The Central Bank of WAEMU decided to devalue the Franc-CFA (XOF) in January 1994 because the goods produced by WAEMU countries were closing to access global markets by overly high prices when the exchange rate of the XOF was fixing at an artificially high level. As a result, economic growth in these countries was low or zero during the 80s and early 90s. To correct this situation, these countries following consultations and the advice of the IMF and France decided boldly to devalue XOF or CFA franc by $50 \%$. The objective of devaluation was to put these countries on a path of sustainable growth by helping them to restore their competitiveness on world markets and improve their balance of payment. As a result, the devaluation encouraged exports over imports [46] and there reduce the deficit of trade balance. We note that WAEMU member as part of small countries (economically) relied on devaluation of the currency XOF. In most of developing economies real exchange rate shows the international competitiveness and high inflation as a result of currency devaluation and expansionary monetary policy.

According to [29], a number of countries, most of the time, small economies and island manage fixed exchange rate and often devalue it as a stabilization strategy. A small (developing countries and island countries) has limited exportable products and therefore relies on imports for consumption and production. Devaluation thus inflates the domestic price and immediately appreciates the real exchange by increasing the large consumption and discouraging the imports used in the domestic production [29]. WAEMU practices fixed type of 
currency regime and the currency is peg ${ }^{4}$ to Euro (currency). The reasons are the stability in the international prices for the conduct of trade and anti-inflation. Under Article 8 of the Statute of the central bank of West African States (BCEAO), the primary objective of the monetary policy of the BCEAO is to make sure of price stability [47].

According to [29], over the past decades, a significant number of countries have moved from a fixed to a flexible exchange rate regime, mainly to allow monetary instruments to have sufficient space to stabilize the domestic economy, while tax measures continue to be fairly rigorous and risky in most countries. Although the effectiveness of the devaluation has not been sustained in a large volume of existing publications, a considerable number of countries maintain the fixed exchange regime. Interestingly, the majority of them are small economies and islands that belong to regions of Africa, the Caribbean and the Pacific.

The impact of investment on trade balance is not statistically significant. The insignificance of Investment (FDI) does not satisfy our expectation because we expect that an increase in FDI will significantly reduce the trade deficit in WAEMU. Foreign direct investment is use as a proxy for investment in our model. Investment led to the improvement of trade balance, especially if the motives of foreign companies are for exports. According to [48], profitable foreign investment generates capital income (and thus spending) at home, and the associated capital outflow should weaken the country currency (dollar), promoting export, at less in principle it can create strong demand at home. A strong capital inflow also pushes up the value of the currency (XOF) and helped create large trade deficit. Foreign investment also stimulates capital in local industry and the creation of new industry. That will boost home productivity and thus will increase export in the long run and reduce the trade deficit. Investment has significant effect on current account balance. The sign of investment (FDI) coefficient satisfies our expectation.

The significance of household consumption and its positive sign (which respect our expectation) mean that an increase in household consumption increases the deficit. That can be explaining by the importation of more consumption products and manufacturing products.

Considering the results, we can say that the mean determinants of Trade Balance in case of WAEMU are Money supply (M2), Real Exchange Rate, Income, Inflation and Household consumption expenditure. The mean determinants of Current Account balance in case of WAEMU are Money supply (M2), Exchange Rate, Income and Investment.

\subsection{Causality Test}

The null hypothesis here is, Ho: the excluded or independent variables do not

${ }^{4}$ With the introduction of the Euro in 1999, WAEMU pegged it exchange rate regime to the Euro. $\mathrm{XOF}$ is peg to euro because France was no longer going to use the French franc but the Euro after 1999. WAEMU had to peg against the new currency of its political and economic partner to respect the agreement between France and its members. 
Granger-cause Equation variables (the trade balance and current account balance), and our alternative hypothesis is Ha: the excluded or independent variables do Granger-causes Equation variables. In this analysis, we are interested in the causation of Excluded variables on the equation. So we mainly focus on the causality of independents variables (especially money supply, income and exchange rate, inflation and investment) on the dependent variables (the trade balance and current account). So we clearly test the causality between Money supply (M2), real Exchange rate, Income, inflation, investment, household consumption expenditure, and the dependent (trade balance and current account).

The causality test Table 5 shows a statistical significance between money supply (M2), Exchange rate, Inflation, income and household consumption expenditure. They have then a causal effect on the trade balance. In another hand, Investment (FDI) does not cause the trade balance. The overall causality model is statistically significant. It shows that our independent variables Granger-cause trade balance.

In the other side, Money Supply, exchange rate, Income and investment granger-cause current account Table 6 . Inflation and household consumption expenditure do not granger-cause current account balance because they are statistically insignificant. We can conclude that the variables as a whole cause the current account balance.

In the other side, money supply, exchange rate, Income and investment granger-cause current account Table 6. Inflation and household consumption

Table 5. Granger causality results on trade balance.

\begin{tabular}{|c|c|c|c|}
\hline Equation & Excluded & Chi2 & Prob $>$ chi 2 \\
\hline \multirow{7}{*}{ Trade balance } & Money supply (M2) & 74.568 & 0.000 \\
\hline & Real exchange rate & 7.120 & 0.008 \\
\hline & Income & 5.393 & 0.020 \\
\hline & Inflation & 7.176 & 0.007 \\
\hline & Investment & 0.091 & 0.763 \\
\hline & House-hold consumption expenditure & 14.596 & 0.000 \\
\hline & All & 117.472 & 0.000 \\
\hline
\end{tabular}

Table 6. Granger causality results on current account balance.

\begin{tabular}{cccc}
\hline Equation & Excluded & Chi2 & Prob > chi2 \\
\hline & Money supply (M2) & 11.97 & 0.001 \\
& Real exchange rate & 36.01 & 0.000 \\
Current & Income & 4.34 & 0.037 \\
account & Inflation & 3.04 & 0.081 \\
balance & Investment & 11.07 & 0.001 \\
& House-hold consumption expenditure & 0.12 & 0.725 \\
& All & 56.78 & 0.000 \\
\hline
\end{tabular}


expenditure do not granger-cause current account balance because they are statistically insignificant. We can conclude that the variables as a whole cause the current account balance.

\subsection{Model Validity and Stability Test}

Here, a test of whether the model is valid is performing by running a stability test. The stability test reveals that the system respects the stability condition so the model is stable. The model is stable because of all the modulus or absolute value of complex root from Table 7 (stability of the model with Trade balance as dependent variable) and Table 8 (stability of the model with current account Trade balance as dependent variable), are less than 1 which means the model is stationary. The stability of the model is also confirmed by Figure 2(a) and Figure 2(b) where all the points are inside the circles. We can say that the stability test reveals the validity of our Panel VAR model.

Table 7. Stability test*.

\begin{tabular}{ccc}
\hline & Eigenvalue stability condition & \\
\hline Real & Eigen-value & \\
\hline 0.977 & Imaginary & Modulus \\
-0.500 & 0 & 0.977 \\
-0.500 & -0.111 & 0.512 \\
0.457 & 0.111 & 0.512 \\
0.457 & -0.048 & 0.460 \\
-0.130 & 0.484 & 0.460 \\
-0.130 & -0.071 & 0.014
\end{tabular}

*Trade balance as dependent variable as dependent variable.

Table 8. Model stability test*.

\begin{tabular}{ccc}
\hline & Eigenvalue stability condition & \\
\hline Real & Eigen-value & \\
0.952 & Imaginary & Modulus \\
0.485 & 0 & 0.952 \\
0.485 & -0.308 & 0.575 \\
0.045 & 0.308 & 0.575 \\
-0.429 & 0 & 0.452 \\
-0.062 & 0 & 0.429 \\
-0.062 & -0.141 & 0.155 \\
\hline
\end{tabular}

*Current account balance as dependent variable. 


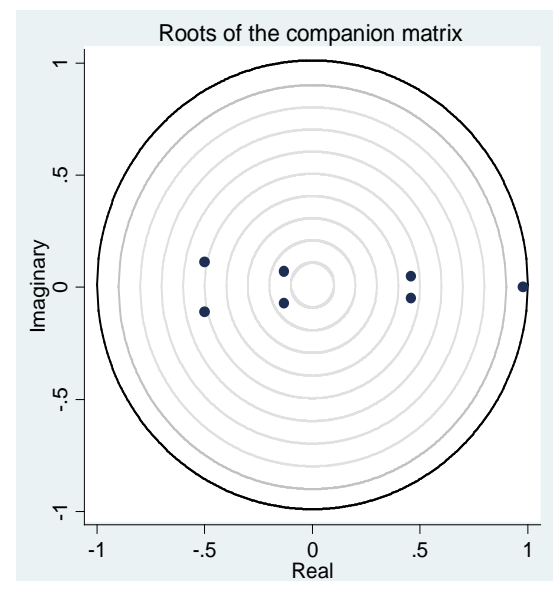

(a)

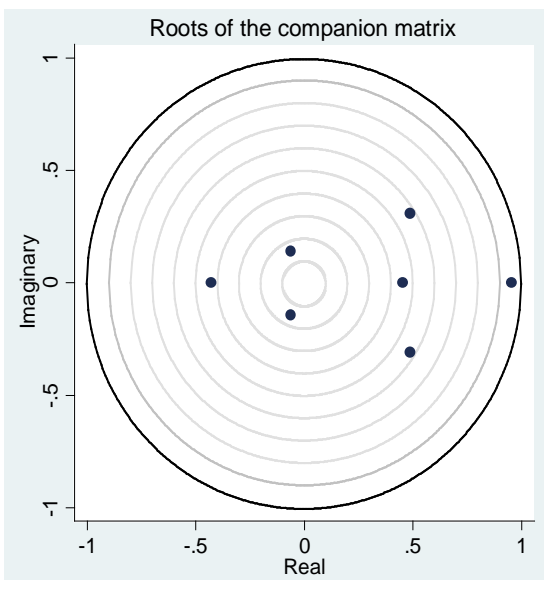

(b)

Figure 2. (a) Stability/stationary condition (trade balance as dependent variable); (b) Stability/stationary condition (trade balance as dependent variable).

The necessary condition for the use of an estimated VAR is that it must be stable. Stability implies convergence, hence allows the impulse responses to shocks to settle down after some oscillations. A formal test for the stability of VAR is to examine the roots of the Autoregressive Characteristic polynomial of VAR. When all the inverse roots are within the circle, then the VAR is said to be stable. Figure 2(a) \& Figure 2(b) reveal that the model meets the stability condition and is consequently robust and we can use it for policy analysis.

\subsection{Variance Decomposition Analysis}

Here we develop from the estimated Panel VAR a variance decomposition Analysis. It works out that variance decompositions and impulse response functions which are tools to measure the dynamic matches and power of causal links between variables in the method. The estimation results are illustrated in Table 9 and Table 10. We provide only the variance decompositions of trade balance and current account for space saving. Own shocks usually explain more of the error variance as shown in Table 9 and Table 10 despite the fact that other variables in the system will be affected. According to our estimates Table 9 among the $\mathrm{six}^{5}$ macroeconomic shocks, the exchange rate shock accounts for the highest part of the changes in the forecast error variance of the trade balances in WAEMU. We notice that the effect of inflation on trade balance increases over time. We notice that the exchange effect on trade balance increases over time from 4 to 8 percent.

The contribution of money supply shock to trade balance is almost constant form the first to ten year horizon with 5 percent. The innovation of $1 \%$ of the yearly forecast error variance in Trade balance is accounted for $1 \%$ in the second year and $3 \%$ in year three from income. From four to ten year horizon the contribution of income shock account for $4 \%$. A shock in inflation will account for

${ }^{5}$ Trade Balance, Money Supply (M2), Exchange Rate, Income. Inflation, Investment and Household Consumption Expenditure shocks. 
Table 9. Forecast-error variance decomposition: trade balance.

\begin{tabular}{|c|c|c|c|c|c|c|c|}
\hline \multicolumn{8}{|c|}{ Impulse variable } \\
\hline $\begin{array}{c}\text { Trade } \\
\text { balance }\end{array}$ & $\begin{array}{l}\text { Trade } \\
\text { balance }\end{array}$ & $\begin{array}{l}\text { Money } \\
\text { supply } \\
\text { (M2) }\end{array}$ & $\begin{array}{l}\text { Real } \\
\text { exchange } \\
\text { rate }\end{array}$ & Income & Inflation & Investment & $\begin{array}{c}\text { Household } \\
\text { consumption } \\
\text { expenditure }\end{array}$ \\
\hline \multicolumn{8}{|c|}{ Response variable and forecast } \\
\hline 1 & 1 & 0 & 0 & 0 & 0 & 0 & 0 \\
\hline 2 & 0.84 & 0.05 & 0.04 & 0.01 & 0.008 & 0.0003 & 0.02 \\
\hline 3 & 0.81 & 0.05 & 0.04 & 0.03 & 0.009 & 0.006 & 0.03 \\
\hline 4 & 0.79 & 0.05 & 0.05 & 0.04 & 0.009 & 0.007 & 0.03 \\
\hline 5 & 0.78 & 0.05 & 0.06 & 0.04 & 0.009 & 0.008 & 0.03 \\
\hline 6 & 0.77 & 0.05 & 0.06 & 0.04 & 0.009 & 0.008 & 0.03 \\
\hline 7 & 0.76 & 0.05 & 0.07 & 0.04 & 0.01 & 0.009 & 0.03 \\
\hline 8 & 0.76 & 0.05 & 0.07 & 0.04 & 0.01 & 0.008 & 0.03 \\
\hline 9 & 0.76 & 0.05 & 0.08 & 0.04 & 0.01 & 0.008 & 0.03 \\
\hline 10 & 0.75 & 0.05 & 0.08 & 0.04 & 0.01 & 0.008 & 0.03 \\
\hline
\end{tabular}

Table 10. Forecast-error variance decomposition: current account.

\begin{tabular}{|c|c|c|c|c|c|c|c|}
\hline \multicolumn{8}{|c|}{ Impulse variable } \\
\hline $\begin{array}{l}\text { Current } \\
\text { account } \\
\text { balance }\end{array}$ & $\begin{array}{l}\text { Current } \\
\text { account } \\
\text { balance }\end{array}$ & $\begin{array}{c}\text { Money } \\
\text { supply } \\
\text { (M2) }\end{array}$ & $\begin{array}{l}\text { real } \\
\text { exchange } \\
\text { rate }\end{array}$ & Income & Inflation & Investment & $\begin{array}{c}\text { Household } \\
\text { consumption } \\
\text { expenditure }\end{array}$ \\
\hline \multicolumn{8}{|c|}{ Response variable and forecast } \\
\hline 1 & 1 & 0 & 0 & 0 & 0 & 0 & 0 \\
\hline 2 & 0.87 & 0.03 & 0.05 & 0.005 & 0.0007 & 0.03 & 0.0002 \\
\hline 3 & 0.74 & 0.04 & 0.16 & 0.005 & 0.003 & 0.03 & 0.0004 \\
\hline 4 & 0.63 & 0.04 & 0.27 & 0.004 & 0.004 & 0.03 & 0.0004 \\
\hline 5 & 0.56 & 0.03 & 0.35 & 0.003 & 0.005 & 0.03 & 0.0004 \\
\hline 6 & 0.51 & 0.03 & 0.41 & 0.003 & 0.005 & 0.02 & 0.0003 \\
\hline 7 & 0.47 & 0.03 & 0.45 & 0.003 & 0.005 & 0.02 & 0.0003 \\
\hline 8 & 0.44 & 0.03 & 0.48 & 0.003 & 0.005 & 0.02 & 0.0003 \\
\hline 9 & 0.42 & 0.02 & 0.51 & 0.003 & 0.005 & 0.02 & 0.0003 \\
\hline 10 & 0.40 & 0.02 & 0.53 & 0.003 & 0.006 & 0.02 & 0.0003 \\
\hline
\end{tabular}

$0.8 \%$ in year two. It account for $0.09 \%$ from three to six year horizon and account for $1 \%$ in the long run (ten-year horizon) on trade balance. We can explain it by the impact of inflation control policy of WAEMU countries. We notice also that the effect of inflation on trade balance increases over time. The contribution of investment (FDI) shock is $0.03 \%$ in year two. The contribution rise and vary between $6 \%$ and $9 \%$ from six to 10 year horizon. The household consumption expenditure shock also increases form $2 \%$ to $3 \%$. So the portion of trade balance fluctuations explained by all independent variables incessantly in- 
crease at long run perspective.

According to the estimate illustrate in Table 10 of Panel Forecast Error Variance Decomposition, the fraction of Current Account Balance forecast error variance attributed to money supply (M2) shock is $3 \%$ for the second year, $4 \%$ in the third and fourth year. It falls to $3 \%$ for the fifth to eighth year and $2 \%$ for ninth and tenth year. From the four (4) year horizon to ten (10) year the explanatory power of money supply (M2) decreased by $2 \%$. The real exchange rate shock attributes $5 \%$ to the forecast error variance of the Current Account balance for the second period to 53\% in the tenth year horizon. The fraction of WAEMU current Account forecast error variance attributable to variances in the real exchange rate is relatively large comparing to the other variables. From year one to year ten, innovation or shock in income account for $0.5 \%$ to $0.3 \%$ Current Account balance. The shock is 0.5 and $0.4 \%$ in the third and fourth year and fall by $1 \%$ from fifth to tenth year horizon (3\%). The fraction of Current Account balance forecast error variance attributed to inflation is $0.07 \%$ for the second year. It increases between $0.3 \%$ in third year to $0.6 \%$ in tenth year with $0.5 \%$ between fifth to ninth years. Shock in investment contributes to $3 \%$ from second to fifth year and decrease to $2 \%$ from six to tenth year horizon. We can explain the decrease by the rise of political instability, the insecurity in the region and the rising insecurity in the neighboring countries like Nigeria and Libya.

\subsection{Impulse Response Function}

The factors could readily explore one variable impact on another. However, with the aim of examining the impact of external shocks on the variables, we use Impulse Response Function (IRF) in Panel series analysis proposes by [26]. IRF generate the time track of dependents variables in the Panel VAR, to shocks from entire explanatory variables. It clarifies how an expected variation in one variable in the starting influences the other through time. We are examining the shocks coming from the error term to Money supply (M2), Exchange rate, Income, Inflation, Investment, House consumption expenditure, Government Consumption-Expenditure and the way they change the trade and current account balance. The exogenous variables are discarded in the notation and focus on the autoregressive structure of the VAR panel in Equation (7). As state by [26] [49] and [50] both show that a VAR model is stable if all moduli of the companion matrix $\bar{A}$ are strictly less than one, where Stability forms the companion matrix implies that the panel VAR is invertible and has an infinite-order Vector Moving Average (VMA) representation, providing known interpretation to estimated impulse response functions and forecast error variance decompositions [26].

$$
\bar{A}=\left[\begin{array}{ccccc}
A_{1} & A_{2} & \cdots & A_{p} & A_{p-1} \\
I_{k} & 0_{k} & \cdots & 0_{k} & 0_{k} \\
0_{k} & I_{k} & \cdots & 0_{k} & 0_{k} \\
\vdots & \vdots & \ddots & \vdots & \vdots \\
0_{k} & 0_{k} & \cdots & I_{k} & 0_{k}
\end{array}\right]
$$


Taking into account the multivariate structure of Equation (7) for Trade balance and current account balance, the equation for Impulse Response Function $\Phi_{i}$ may be computed by rewriting the model as an infinite vector moving-average, where $\Phi_{i}$ are the VMA parameters [26] and is set as:

$$
\Phi_{i}= \begin{cases}I_{k}, & i=0 \\ \sum_{j=1}^{i} \Phi_{t-j} A_{j}, & i=1,2, \mathrm{n}\end{cases}
$$

Figure 3 illustrates the panel Impulse Response function (IRF) of trade balance (TRB) to money supply (M2), Exchange Rate (REXRAT), Income, inflation, investment and household consumption expenditure. The horizontal axis has the time horizon for ten years, and the vertical axis is the responses of our dependent variable, trade balance to the impulse variables. The central line is the calculated values of the response function. The graph: response of TRB to money supply (M2) shows that one period shock in M2 has a negative impact on trade balance but it improves over time but in the long run. The figure shows that the trade balance negatively responds to an impulse in money supply for about two years before it fluctuates and becoming steady from four year. We observe a different situation concerning the Response of trade balance (TRB) to real exchange rate (REEXRAT). The impact effect of the exchange rate is positive and statistically significant. First, the impact effect of income is positive but will give a fluctuating reaction. It decreases in the first year then increase until the third year. The response of the trade balance to income will start becoming steady at five-year horizon. The response of trade balance to inflation is all positive at each time responsive period. Figure 3 also reveals that trade balance responds positively to a shock in investment (FDI) between one to six years before it subsided to zero. Finally, the impact effect of household consumption is negative.

Figure 4 illustrates the panel Impulse Response of current account balance (CA) to money supply (M2), real exchange rate (REXRAT), Income, and other variables. One period shock in money supply is first negative then become positive between two to six year and dies down to zero. The highest effect of money supply is on the second year. The current account balance does react significantly positively to innovation in exchange rate. It responds positively for three years and then the value fluctuates around the line zero. We can say that a
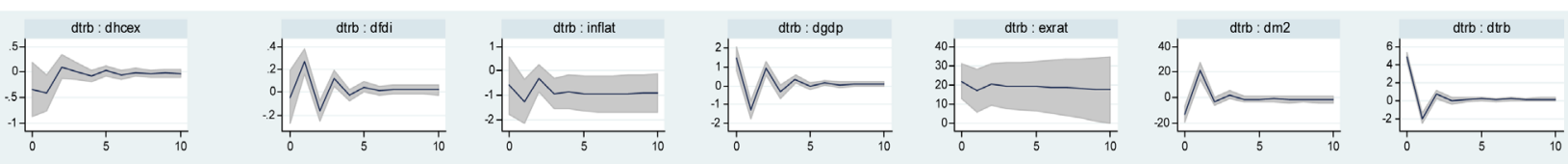

step

$95 \% \mathrm{Cl}$

\section{Orthogonalized IRF}

impulse: response

Figure 3. Impulse response functions of trade balance. 

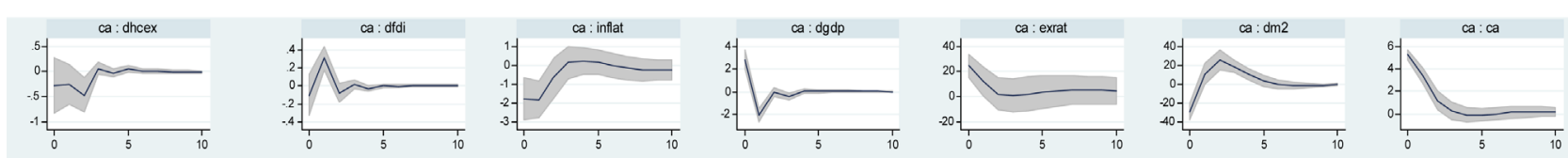

step

$95 \% \mathrm{Cl}$

\section{Orthogonalized IRF}

impulse: response

Figure 4. Impulse response functions of current account balance.

shock in exchange rate makes current account balance to react positively for and then become steady. In over side, the response to innovation in income fluctuates for about four years then dies down to zero. The lowest negative effect is on the first year. The almost all the response from inflation is negative. The effect of investment on current account balance first is negative then become positive and fluctuates until five year. The highest effect is on the first year and the lowest is on the third year. The effect of impulse in household consumption expenditure is negative before becoming steady around year five.

\section{Conclusions}

In this paper, we study empirically the relationship between the trade and current account balance deficit and some main economic variables proposed by some previous empirical literature. We use a sample of eight countries with a continuing deterioration in trade and the current account. These countries are members of West African Economic and Monetary Union (WAEMU) and we estimated the model with panel data by Panel VAR method developed by [26]. Then we estimate forecast variance decomposition and the impulse response functions for ten years. The persistence of trade and current account deficit in WAEMU's countries for so many years motivates the study.

The estimation shows a significant and negative nexus between money supply (M2), household consumption expenditure and trade balance. The analysis shows also a significant but positive relation between Exchange rate, income, inflation and the trade balance. The effect of investment (FDI) on trade balance is not significant.

The analysis indicates statistically significant and negative effects of money supply (M2), investment on current account. The result indicates a positive and significant relationship between Exchange rate, income and current account balance. Inflation and Household consumption expenditure appear to have insignificant effect on the current account balance.

The Granger causality test reveals a statistical significance between money supply (M2), Exchange rate, income and Inflation, Household Consumption Expenditure. We conclude that they have a causal effect on the trade balance. In other side, investment (FDI) does not cause the trade balance. The result indicates that Money Supply, Exchange rate, Income and investment granger-cause current account balance. Inflation and household consumption expenditure do 
not cause current account balance. The shocks study shows that shocks in money supply, exchange rate, and income will contribute more to improve WAEMU trade balance. In other side, shock in money supply, exchange rate and investment improve more current account balance.

According to our analysis, we can say that the mean determinants of Trade Balance in case of WAEMU are Money supply (M2), Exchange Rate, Income, Inflation and Household consumption expenditure. The mean determinants of Current Account balance in case of WAEMU are Money supply (M2), Exchange Rate, Income and Investment (FDI).

From a policy perspective we can propose from the Analysis is that the deficit in the trade and the current account balance, concerning WAEMU, can be reduced or corrected via some policies as follow:

WAEMU countries should import more capital goods and machinery in order boost home productivity. They should export value added goods instead of raw materials and primary products. Manufacture industry should be developing in the objective to reduce the import of more manufacturing goods. The exports of most WAEMU countries are not diversified. Countries like Burkina, Mali, Niger, and Togo rely mostly on the export of mining products. Countries like Cote d'Ivoire and Benin rely mostly on the export of agricultural products and mineral products. There should have a diversification of export products.

WAEMU countries should stress policies on income growth. Policies to promote economic growth are necessary. WAEMU should go through or decide adequate monetary policy to increase or decrease the Money supply according to the situation of the economy. WAEMU should adopt appropriate exchange rates policy by devaluing or evaluate the currency to correct the deficit of trade and current account.

A healthier investment climate is important to encourage more multinational companies to invest in WAEMU countries, especially those countries in which the deficit persists.

We limit this research to the trade balance and current account in West African Economic and Monetary Union (WAEMU). The period of study is limited to the period of thirty four years (1980-2013) using only panel VAR method. For further research, we intend to consider all the countries which share the same currency which is the Franc CFA (XOF) by including the CEMAC countries. Further analysis will consider the capital account for better understand the determinants of the balance of payment deficit. We will also try to analyze the data using more estimation technics for robustness check.

\section{References}

[1] Falk, M. (2008) Determinants of the Trade Balance in Industrialized Countries. FIW Studien, FIW Research Reports, 013, 1-31.

[2] Moses, J.S. and Yao, S. (2013) Analysis of the Determinants of Trade Balance: Case Study of Tanzania. International Journal of Business and Economics Research, 2 , 134-141. https://doi.org/10.11648/j.ijber.20130206.13

[3] IMF (2013) West African Economic and Monetary Union (WAEMU). 
http://www.imf.org/external/pubs/ft/scr/2013/cr1392.pdf

[4] BCEAO (2014) Rapport sur le Commerce Extérieur de l'UEMOA en 2014. http://www.bceao.int/IMG/pdf/rapport_sur_le_commerce_exterieur_de_l_uemoa_e $\underline{\mathrm{n} \_2014 . p d f}$

[5] BCEAO (2014) Balance des Paiements et Position Extérieure Globale Régionales de L'UEMOA au Titre de L'Année 2014.

http://www.bceao.int/IMG/pdf/balance_des_paiements_et_position_exterieure_glo bale_regionales_de_1_uemoa_au_titre_de_l_annee_2014.pdf

[6] IMF (2016) West African Economic and Monetary Union. IMF Country Report No. $16 / 96$.

[7] Edward, N. (2010) The Determinants of Trade Balance in Kenya: An Empirical Analysis. 1970-2010.

[8] İrhan, H.B., Alacahan, N.D. and Korap, L. (2011) An Empirical Model for the Turkish Trade Balance: New Evidence from ARDL Bounds Testing Analyses. Ekonometri ve İstatistik Say1, 14, 38-61.

[9] ZakirSaadullah Khan, M. and Ismail, H.M. (2012) Determinants of Trade Balance of Bangladesh: A Dynamic Panel Data Analysis. Bangladesh Development Studies, 35, 45-65.

[10] Rose, A.K. (1991) The Role of Exchange Rate in a Popular Model of International Trade: Does the "Marshall-Lerner" Condition Hold? Journal of International Economics, 30, 301-316. https://doi.org/10.1016/0022-1996(91)90024-Z

[11] Himarios, D. (1989) Do Devaluations Improve the Trade Balance? The Evidence Revisited. Economic Inquiry, 27, 143-168. https://doi.org/10.1111/j.1465-7295.1989.tb01169.x

[12] Bahmani-Oskooee, M. (2001) Nominal and Real Effective Exchange Rates of Middle Eastern Countries and Their Trade Performance. Applied Economics, 33, 103-111. https://doi.org/10.1080/00036840122490

[13] Sayuni, M. (2006) Determinants of Trade Balance in Tanzania. A Research Paper towards the Fulfillment of Masters of Arts Degree in Economic Policy Management, Makerere University, Kampala.

[14] Duasa, J. (2007) Determinants of Malaysian Trade Balance: An ARDL Bound Testing Approach. Global Economic Review, 36, 89-102.

https://doi.org/10.1080/12265080701217405

[15] Liew, K.S., Lim, K.P. and Hussain, H. (2003) Exchange Rates and Trade Balance Relationship: The Experience of ASEAN Countries. International Trade, 0307003, Econ WPA.1-11.

[16] Rose, A.K. and Yellen, J.L. (1989) In There a J-Curve? Journal of Monetary Economics, 24, 53-68. https://doi.org/10.1016/0304-3932(89)90016-0

[17] Rahman, M., Mustafa, M. and Burckel, D.V. (1997) Dynamics of the Yen-Dollar Real Exchange Rates and the US-Japan Real Trade Balance. Applied Economics, 29, 661-664. https://doi.org/10.1080/000368497326868

[18] Mahdavi, S. and Sohrabian, A. (1993) The Exchange Value of the Dollar and the US Trade Balance: An Empirical Investigation Based on Cointegration and Granger Causality Tests. The Quarterly Review of Economics and Finance, 33, 343-358. https://doi.org/10.1016/1062-9769(93)90003-3

[19] Greenwood, J. (1984) Non-Traded Goods, the Trade Balance and the Balance of Payments. The Canadian Journal of Economics, 17, 806-823.

https://doi.org/10.2307/135075 
[20] Menzie, C. and Eswar, S.P. (2000) Medium-Term Determinants of Current Accounts in Industrial and Developing Countries: An Empirical Exploration. National Bureau of Economic Research, Working Paper 7581.

[21] Grigorios, B., John, M.P. and Papazoglou, C. (2008) The Determinants of the Greek Current Account Deficit: The EMU Experience. Journal of International and Global Economic Studies, 1, 105-122.

[22] Abbas, S.M.A., Bougha-Hagbe, J., Fatas, A.J., Mauro, P. and Velloso, R.C. (2010) Fiscal Policy and Current Account. IMF Working Paper No. WP/10/121. www.imf.org/ /media/Websites/IMF/imported-full-textpdf/external/pubs/ft/wp/20 10/_wp10121.ashx

[23] Kayikçi, F. (2012) Determinants of the Current Account Balance in Turkey: Vector Auto Regression (VAR) Approach. African Journal of Business and Management, 6 , 5725-5736.

[24] Endegnanew, T., Yartey, C. and Jones, T. (2012) Fiscal Policy and Current Account: Are Microstates Different? IMF Working Paper No. WP/12/51.

[25] Kimani, S.M. (2014) Determinants of Current Account Balance in Kenya. Master Degree Thesis, School of Economics, Kenyatta University, Kahawa.

[26] Abrigo, M.R.M. and Inessa, L. (2016) Estimation of Panel Vector Autoregression in Stata: A Package of Programs. Working Paper No. 16-2.

http://www.economics.hawaii.edu/research/workingpapers/WP_16-02.pdf

[27] Bahmani-Oskooee, M. and Niroomand, F. (1998) Long-Run Price Elasticities and the Marshall-Lerner Condition Revisited. Economics Letters, 61, 101-109. https://doi.org/10.1016/S0165-1765(98)00147-5

[28] Bahmani-Oskooee, M. (1992) What Are the Long-Run Determinants of the U.S. Trade Balance? Journal of Post Keynesian Economics, 15, 85-97. https://doi.org/10.1080/01603477.1992.11489927

[29] Prakash, K. and Maiti, D. (2016) Does Devaluation Improve Trade Balance in Small Island Economies? The Case of Fiji. Economic Modeling, 55, 382-393. https://doi.org/10.1016/j.econmod.2016.02.023

[30] Holtz-Eakin, D., Newey, W. and Rosen, H.S. (1988) Estimating Vector Autoregressions with Panel Data. Econometrica, 56, 1371-1395. https://doi.org/10.2307/1913103

[31] Hansen, L.P. (1982) Large Sample Properties of Generalized Method of Moments Estimators. Econometrica, 50, 1029-1054. https://doi.org/10.2307/1912775

[32] Prais, S.J. (1961) Some Mathematical Notes on the Quantity Theory of Money in a Small Open Economy. Staff Papers-International Monetary Fund, 8, 212-226.

[33] Mundell, R.A. (1968) International Economics. Macmillan, New York.

[34] Mundell, R.A. (1971) Monetary Theory. Goodyear, Pacific Palisades.

[35] İsmail, Ç. and Burak, Ç. (2008) The Determinants of the Current Account Balance in Inflation Targeting Countries. Iktisat Iş̧letme ve Finans, 23, 111-131. https://www.researchgate.net/publication/23533393

[36] Nadal De Simone, F. (1997) Current Account and Exchange Rate Behavior under Inflation Targeting in a Small Open Economy. Central Bank of New Zealand, Discussion Papers G97/4.

http://www.rbnz.govt.nz/-/media/ReserveBank/Files/Publications/Discussion\%20pa pers/1997/g97-4.pdf

[37] Svensson, L.E.O. (2000) Open-Economy Inflation Targeting. Journal of International Economics, 50, 155-183. https://doi.org/10.1016/S0022-1996(98)00078-6 
[38] Fabio, C. and Matteo, C. (2013) Panel Vector Autoregressive Models a Survey. European Central Bank, Working Paper Series, 1507, 2-3.

[39] Tarik, H.A. (2001) Variance Decomposition Analysis of the Demand for Foreign Money in Egypt. Journal of Economic Studies, 28, 122-135. https://doi.org/10.1108/EUM0000000005427

[40] Andrews, D.W.K. and Lu, B. (2001) Consistent Model and Moment Selection Procedures for GMM Estimation with Application to Dynamic Panel Data Models. Journal of Econometrics, 101, 123-164. https://doi.org/10.1016/S0304-4076(00)00077-4

[41] Akaike, H. (1969) Fitting Autoregressive Models for Prediction. Annals of the Institute of Statistical Mathematics, 21, 243-247. https://doi.org/10.1007/BF02532251

[42] Schwarz, G. (1978) Estimating the Dimension of a Model. The Annals of Statistics, 6, 461-464. https://doi.org/10.1214/aos/1176344136

[43] Risannen, J. (1978) Modeling by Shortest Data Description. Automatica, 14, 465471. https://doi.org/10.1016/0005-1098(78)90005-5

[44] Akaike, H. (1977) On Entropy Maximization Principle. In: Krishnaiah, P.R., Ed., Applications of Statistics, North-Holland, Amsterdam.

[45] Hannan, E.J. and Quinn, B.G. (1979) The Determination of the Order of an Autoregression. Journal of the Royal Statistical Society. Series B, 41, 190-195.

[46] IMF (n.d.) Informations générales. https://www.imf.org/external/pubs/ft/fabric/fra/backgrnd.htm\#three

[47] BCEAO (n.d.) Objectifs de la Politique monétaire. http://www.bceao.int/Objectifs-de-la-Politique.html

[48] Bernanke, B.S. (2015) Why Are Interest Rates So Low, Part 3: The Global Savings Glut.

http://www.brookings.edu/blogs/ben-bernanke/posts/2015/04/01-why-interest-rates -low-global-savings-glut

[49] Lutkepohl, H. (2005) New Introduction to Multiple Time Series Analysis. Springer, New York. https://doi.org/10.1007/978-3-540-27752-1

[50] Hamilton, J.D. (1994) Time Series Analysis. Princeton University Press, Princeton.

\section{Submit or recommend next manuscript to SCIRP and we will provide best service for you:}

Accepting pre-submission inquiries through Email, Facebook, LinkedIn, Twitter, etc. A wide selection of journals (inclusive of 9 subjects, more than 200 journals)

Providing 24-hour high-quality service

User-friendly online submission system

Fair and swift peer-review system

Efficient typesetting and proofreading procedure

Display of the result of downloads and visits, as well as the number of cited articles

Maximum dissemination of your research work

Submit your manuscript at: http://papersubmission.scirp.org/

Or contact tel@scirp.org 